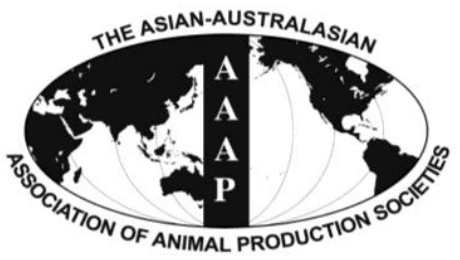

Asian-Aust. J. Anim. Sci.

Vol. 25, No. 12 : 1660-1666 December 2012

http://dx.doi.org/10.5713/ajas.2012.12331

www.ajas.info

pISSN 1011-2367 elSSN 1976-5517

\title{
MHC-DQB1 Variation and Its Association with Resistance or Susceptibility to Cystic Echinococcosis in Chinese Merino Sheep
}

\author{
Wenqiao Hui ${ }^{\mathrm{a}}$, Hong Shen ${ }^{\mathrm{a}}$, Song Jiang and Bin Jia* \\ College of Animal Science and Technology, Shihezi University, Road Beisi, Shihezi 832003, Xinjiang, China
}

\begin{abstract}
Cystic echinococcosis (CE), one of the world's most geographically widespread diseases, still represents a considerable economic and public health significance, although a variety of methods has been used to control the disease. It has been demonstrated that genetic factors, especially variations in MHC loci, can influence the outcome of CE infection in the human population. The study described here was designed to determine whether variation in MHC-DQB1 was associated with susceptibility or resistance to CE in sheep. If so, it would lay a theoretical foundation for breeding disease resistance sheep in future. This study was carried out on 204 Chinese Merino sheep, including $101 \mathrm{CE}$ sheep and 103 healthy controls. The polymorphism of MHC-DQB1 exon 2 was detected by polymerase chain reaction-restriction fragment length polymorphism (PCR-RFLP) method, and $x^{2}$ test was used to compare genotype frequencies between CE sheep and healthy controls. A total of 22 alleles and 42 genotypes were identified in DQB1 exon 2 in Chinese Merino sheep. In addition, $x^{2}$ test showed that frequencies of DQB1-TaqIaa and DQB1-HaeIIInn genotypes were significantly higher in the healthy group ( $82.5 \%$ and $57.3 \%$, respectively) than that in the $\mathrm{CE}$ group $(57.4 \%$ and $28.9 \%$, respectively) (both $\mathrm{p}$ values $=0$, OR $=$ $0.286,0.303$, respectively), suggesting that these genotypes appeared to be associated with resistance to CE. Whereas, frequencies of DQB1-TaqIab and DQB1-HaeIIImn genotypes were significantly higher in the CE group (36.9\% and 32.0\%, respectively), as compared with the healthy group ( $16.5 \%$ and $11.15 \%$, respectively) $(\mathrm{p}=0.001,0.001$ and $\mathrm{OR}=2.963,3.629$, respectively), indicating that these genotypes might be associated with susceptibility to CE. It is concluded that the genetic polymorphism within MHC-DQB1 might influence immune responses to pathogens, thus leading to the development of CE or protection against CE in Chinese Merino sheep, which would pave the way for breeding disease resistance sheep in future. (Key Words: Chinese Merino Sheep, MHC-DQB1 Exon 2, Genotype, Cystic Echinococcosis)
\end{abstract}

\section{INTRODUCTION}

Cystic echinococcosis (CE), a chronic parasitic zoonosis, is caused by infection with the larval stage of the cestode Echinococcus granulosus (E. granulosus), resulting in the development of cysts in humans and domestic animals (Conchedda et al., 2008). The disease presents high risk to human health in areas of poor sanitary and hygiene conditions. Also, CE causes considerable health problems in animals and economical disadvantages due to production loss, as animals infected with this disease often suffer reductions in live weight gain, milk yield, fertility rates and the value of wool or other products (Torgerson, 2003). Hence, CE control is a vital part of health and production management in domestic animals, especially in sheep,

\footnotetext{
* Corresponding Author: Bin Jia. Tel: +86-993-2058079, Fax: +86-993-2038582, E-mail: jiabin@shzu.edu.cn

${ }^{a}$ These authors contributed equally to this work. Submitted Jun. 13, 2012; Accepted Aug. 22, 2012; Revised Sept. 15, 2012
}

because sheep appear to be highly susceptible to infection (Lightowlers et al., 1999). A variety of methods have been applied to minimize the impact of $\mathrm{CE}$, including grazing management, medical control and vaccination. These methods have the advantage of being easy to plan and record, and historically, have been effective (Zhang et al., 2003). However, using drugs frequently can cause problems like parasites developing resistance to drugs and public concern about chemical residues in animal products and the environment (Sangster, 1999). On the other hand, vaccination is expensive for pastoral areas in northwestern China. A new approach that relies on sustainable methods, therefore, should be employed.

Major histocompatibility complex (MHC), an organized cluster of tightly-linked genes, encodes the molecules that bind processed peptide antigens including parasite-derived peptides and presents them to T-lymphocytes, thereby triggering antigen-specific immune responses (Millot, 1978). In sheep, the MHC gene family includes two major 
subfamilies: class I and class II genes (Klein, 1986). Among sheep MHC class II genes, the expressed DRB1 and DQB1 loci have been found to be highly polymorphic (Woodal et al., 1997; Konnai et al., 2003b; Sun et al., 2004). In particular, a high polymorphism level is present in exon 2, which encodes the antigen-binding site (Outteridge et al., 1996; Konnai et al., 2003a, b). Variation in these genes may impact immune responses to pathogens, which may lead to variation in disease resistance. In the recent years, a large number of meaningful association studies have been carried out in sheep, especially on resistance to: i) nematodiasis such as gastronintestinal nematodiasis (Charon et al., 2002; Sayers et al., 2005; Stear et al., 2005); ii) bacterial diseases like bacterial footrot (Escayg et al., 1997); and iii) viral diseases such as BLV-induced ovine lymphoma, Maedi Visna and pulmonary adenocarcinoma viral diseases (Aida, 2001; Konnai et al., 2003b; Larruskain et al., 2010). However, to our knowledge, no study on the MHC-DQB1 gene and $\mathrm{CE}$ association in sheep has been published, although we previously found that different MHC-DRB1 genotypes were associated with different susceptibilities of CE in Kazakh sheep, a native Chinese sheep breed (Li et al., 2010).

Chinese Merino sheep, well known for their characteristics of good wool and meat production, is beneficial to local sheep industry; however, they are relatively more susceptible to CE (Hui et al., 2012). The prevalence of $\mathrm{CE}$ in Chinese Merino sheep causes considerable economic problems due to the loss of production. These losses are of especial significance in Xinjiang (northwestern China) a region of low economic output where sheep production is of particular importance. Hence, it is of great urgency to treat and manage CE in Chinese Merino sheep. An alternative method is to selectively breed sheep for disease resistance using genetic markers.

Our previous study has shown that different MHCDQB1 mRNA expression levels were detected between different outcomes of $\mathrm{CE}$ infections in Chinese Merino sheep (Hui et al., 2012). So, in this study, we were curious to see whether variation in MHC-DQB1 was associated with susceptibility or resistance to $\mathrm{CE}$ in Chinese Merino sheep. If so, it would lay a theoretical foundation for future breeding disease resistance sheep.

\section{MATERIALS AND METHODS}

\section{Animals}

All sheep included in this study were 1-yr-old unrelated female Chinese Merino sheep from the farm located in Mission 165, agricultural division 9, Xinjiang Production and Construction Corps. According to the recommendation of WHO-IWG, ultrasonography and serological methods were combined to distinguish between CE sheep and healthy individuals in the flock. If the sheep were negative for antibodies to hydatid cyst fluid (HCF) antigen, assayed by a commercial ovine hydatidosis ELISA kit (Shenzhen Combined Biotech Co.), and no hydatid cysts present in internal organs as detected by ultrasonography (50 S Tringa Vet, Pie Medical, Netherland), they were designated as the healthy cohort. If the sheep were positive for antibodies to $\mathrm{HCF}$ antigen, and had cysts in the internal organs as determined by ultrasonography, and further had protoscolices visualized by microscopy, they were designated as the CE cohort. Of all the selected sheep, there were $101 \mathrm{CE}$ sheep and 103 healthy controls.

\section{DNA extraction}

Genomic DNA was isolated from the whole blood using phenol-chlorophorm extraction, and stored at $-20^{\circ} \mathrm{C}$ until analysis (Major reagents were from Promega Company and Shanghai Sangon Biological Engineering Technology And Service Co, Ltd.).

\section{PCR amplification for MHC-DQB1 gene}

The second exon of DQB1 was amplified with primers FW: 5'-CCC CGC AGA GGA TTT CGT G-3' and REV: 5'ACC TCG CCG CTG CCA GGT-3' (Amills et al., 2005), sequence logging number Z28523. Genomic DNA (150 ng) was amplified in a total volume of $50 \mu \mathrm{l}$, including $1.5 \mathrm{mM}$ $\mathrm{MgCl}_{2}, 100 \mu \mathrm{M}$ dNTPs, $0.2 \mathrm{mM}$ of each primer, and $2 \mathrm{U}$ of Taq polymerase. Reactions were performed in a thermocycler under the following conditions: one cycle of incubation for $5 \mathrm{~min}$ at $94^{\circ} \mathrm{C}$, followed by 33 cycles of $94^{\circ} \mathrm{C}$ for $30 \mathrm{~s}, 67^{\circ} \mathrm{C}$ for $30 \mathrm{~s}$, and $72^{\circ} \mathrm{C}$ for $45 \mathrm{~s}$, with final extension at $72^{\circ} \mathrm{C}$ for $10 \mathrm{~min}$.

\section{Polymorphism detection by RFLP}

RFLP protocol was carried out to examine the nucleotide sequence variability at the second exon of DQB1 locus, according to the method described by Konnai et al. (2003a), with modifications. Aliquots $(10 \mu \mathrm{l})$ of DQB1 PCR product were digested with $5 \mathrm{U}$ of MroxI, ScaI, SacII, NciI, TaqI, MvaI, and HaeIII, respectively. The condition of restriction enzymes digestions and fragment visualizations can be seen in Table 1. Gene typing method and genotype nomenclature is in accordance with Konnai et al. (2003a) and Li et al. (Table 2).

\section{Statistical analysis}

Data were analyzed with the Statistical Package for Social Science version 13.0 for Windows. In order to assess the statistical significance of association of different genotype and genotype frequencies with CE susceptibility or resistance, the $x^{2}$ test with Yates' correction for continuity 
Table 1. Conditions of restriction enzymes and examination of digested PCR product of MHC-DQB1 exon 2

\begin{tabular}{lcccc}
\hline $\begin{array}{c}\text { Restriction } \\
\text { enzymes }\end{array}$ & $\begin{array}{c}\text { Digest-temperature } \\
\left({ }^{\circ} \mathrm{C}\right)\end{array}$ & $\begin{array}{c}\text { Digest-time } \\
(\mathrm{h})\end{array}$ & $\begin{array}{c}\text { Concentration of } \\
\text { agarose gel }(\%)\end{array}$ & Recognition site \\
\hline TaqI & 65 & 5 & 2.5 & $\mathrm{~T}^{*} \mathrm{CGA}$ \\
MvaI & 37 & 5 & 2.5 & $\mathrm{CC} *(\mathrm{~A} / \mathrm{T}) \mathrm{GG}$ \\
Hae III & 37 & 4 & 2.5 & GG*CC \\
MroxI & 37 & 4 & 2.5 & GAANN*NNTTC \\
ScaI & 38 & 6 & 3.0 & AGT*ACT \\
Sac II & 37 & 4 & 2.5 & CCGC*GG \\
NciI & 37 & 5 & 2.5 & GG $(\mathrm{G} / \mathrm{C}) * \mathrm{CC}$ \\
\hline
\end{tabular}

* Represents recognition site; / Represents recognition of A or T.

was applied. The degree of association was calculated using odds ratio (OR; Dorak, 2006). Significance was accepted at 0.05 for all of the tests.

\section{RESULTS}

\section{PCR amplification of MHC-DQB1 exon 2 genes}

Ovar-DQB1 exon 2 was amplified by PCR with primers FW and REV, and one specific band of 280 bp was observed on $2 \%$ agarose.

\section{MHC- DQB1 RFLP typing}

The following numbers of alleles and RFLP patterns detected with each restriction enzyme were observed in MHC-DQB1: MroxI, 2, 3; ScaI, 2, 3; SacII, 4, 7; NciI, 2, 3; TaqI, 3, 4; MvaI, 6, 16 and HaeIII, 3, 6 (Tables 3 and 4). A total of 22 alleles and 42 RFLP patterns were identified in DQB1 exon 2 in Chinese Merino sheep. Allele frequencies were also calculated at each restriction enzyme site (Table
4). In addition, the Hardy-Weinberg test was performed to detect whether individual variants were in equilibrium at the locus detected. The Chi-Square values of the seven restriction enzymes MroxI, ScaI, SacII, NciI, TaqI, MvaI, and HaeIII were $5.9568(\mathrm{p}>0.05), \quad 80.1527(\mathrm{p}<0.01)$, $24.3947(\mathrm{p}<0.01), 134.3837(\mathrm{p}<0.01), 2.3968(\mathrm{p}>0.05)$, $359.7055(\mathrm{p}<0.01)$ and $78.1706(\mathrm{p}<0.01)$, respectively. The results suggested that the sites of MroxI and TaqI were within Hardy-Weinberg balance, while the sites of the others were not within Hardy-Weinberg balance.

\section{Analysis of association between MHC-DQB1 genotypes and $\mathrm{CE}$}

We compared the distribution of MHC-DQB1 genotypes, both frequency and percentage, and found that higher frequencies were statistically significant in the case of DQB1-TaqIaa and DQB1-HaeIIInn ( $\mathrm{p}=0.000,0.000$, respectively) in the healthy group $(\mathrm{OR}=0.286,0.303 ; 95 \%$ $\mathrm{CI}=0.150-0.544,0.167-0.550$, respectively) than that in

Table 2. The genotypes of PCR-RFLP in ovar-DQB1 exon 2

\begin{tabular}{|c|c|c|c|c|}
\hline \multirow{2}{*}{$\begin{array}{l}\begin{array}{l}\text { Restriction } \\
\text { enzymes }\end{array} \\
\text { TaqI }\end{array}$} & \multicolumn{4}{|c|}{ The genotypes of each restriction enzyme } \\
\hline & $\mathrm{aa}(165 \mathrm{bp} / 115 \mathrm{bp})$ & bb(231 bp/49 bp) & $\begin{array}{l}a b(231 \quad b p / 165 \quad b p / 115 \\
b p / 49 b p)\end{array}$ & $\mathrm{ac}(280 \mathrm{bp} / 165 \mathrm{bp} / 115 \mathrm{bp})$ \\
\hline MroxI & $\mathrm{aa}(280 \mathrm{bp})$ & $\mathrm{bb}(192 \mathrm{bp} / 88 \mathrm{bp})$ & $\mathrm{ab}(280 \mathrm{bp} / 192 \mathrm{bp} / 88 \mathrm{bp})$ & \\
\hline ScaI & $\mathrm{aa}(280 \mathrm{bp})$ & $\mathrm{bb}(174 \mathrm{bp} / 106 \mathrm{bp})$ & $\mathrm{ab}(280 \mathrm{bp} / 174 \mathrm{bp} / 106 \mathrm{bp})$ & \\
\hline$N c i \mathrm{I}$ & $\operatorname{gg}(280 \mathrm{bp})$ & $\mathrm{xx}(140 \mathrm{bp})$ & xg(280 bp/140 bp) & \\
\hline \multirow[t]{2}{*}{ SacII } & $\mathrm{aa}(280 \mathrm{bp})$ & $\mathrm{bb}(140 \mathrm{bp} / 140 \mathrm{bp})$ & $\mathrm{cc}(217 \mathrm{bp} / 63 \mathrm{bp})$ & $\mathrm{ab}(280 / 140 \mathrm{bp} / 140 \mathrm{bp})$ \\
\hline & $\mathrm{ac}(280 \mathrm{bp} / 217 \mathrm{bp} / 63 \mathrm{bp})$ & bd(140 bp/77 bp/63 bp) & $\begin{array}{l}\text { ad(280 bp/140 bp/77 bp/63 } \\
\text { bp) }\end{array}$ & \\
\hline \multirow[t]{2}{*}{ HaeIII } & $\mathrm{aa}(213 \mathrm{bp} / 67 \mathrm{bp})$ & $\begin{array}{l}\mathrm{bb}(127 \mathrm{bp} / 67 \mathrm{bp} / 52 \mathrm{bp} / 34 \\
\mathrm{bp})\end{array}$ & $\begin{array}{l}\mathrm{cc} \\
(179 \mathrm{bp} / 67 \mathrm{bp} / 34 \mathrm{bp})\end{array}$ & $\begin{array}{l}\mathrm{bc}(179 \mathrm{bp} / 127 \mathrm{bp} / 67 \mathrm{bp} / 52 \\
\mathrm{bp} / 34 \mathrm{bp})\end{array}$ \\
\hline & $\begin{array}{l}\mathrm{ab}(213 \mathrm{bp} / 179 \mathrm{bp} / 67 \mathrm{bp} / 34 \\
\mathrm{bp})\end{array}$ & $\begin{array}{l}\mathrm{ac}(213 \mathrm{bp} / 179 \mathrm{bp} / 67 \mathrm{bp} / 34 \\
\mathrm{bp})\end{array}$ & & \\
\hline \multirow[t]{4}{*}{$M v a \mathrm{I}$} & $\mathrm{aa}(198 \mathrm{bp} / 82 \mathrm{bp})$ & $\mathrm{bb}(266 \mathrm{bp} / 14 \mathrm{bp})$ & cc(198 bp/68 bp/14 bp) & $\mathrm{dd}(280 \mathrm{bp})$ \\
\hline & $\begin{array}{l}\text { yy(150 bp/96 bp/20 bp/14 } \\
\text { bp) }\end{array}$ & $\begin{array}{l}\mathrm{zz}(102 \mathrm{bp} / 96 \mathrm{bp} / 48 \mathrm{bp} / 20 \\
\mathrm{bp} / 14 \mathrm{bp})\end{array}$ & $\mathrm{ad}(280 \mathrm{bp} / 198 \mathrm{bp} / 82 \mathrm{bp})$ & $\begin{array}{l}\mathrm{az}(198 \mathrm{bp} / 102 \mathrm{bp} / 96 \mathrm{bp} / 82 \\
\mathrm{bp} / 48 \mathrm{bp} / 20 \mathrm{bp} / 14 \mathrm{bp})\end{array}$ \\
\hline & $\begin{array}{l}\mathrm{bc}(266 \mathrm{bp} / 198 \mathrm{bp} / 68 \mathrm{bp} / 14 \\
\mathrm{bp})\end{array}$ & bd(280 bp/266 bp/14 bp) & $\begin{array}{l}\text { by(266 bp/150 bp/96 bp/20 } \\
\text { bp/14 bp) }\end{array}$ & $\begin{array}{l}\mathrm{bz}(266 \mathrm{bp} / 102 \mathrm{bp} / 96 \mathrm{bp} / 48 \\
\mathrm{bp} / 20 \mathrm{bp} / 14 \mathrm{bp})\end{array}$ \\
\hline & $\begin{array}{l}\mathrm{cd}(280 \mathrm{bp} / 198 \mathrm{bp} / 68 \mathrm{bp} / 14 \\
\mathrm{bp})\end{array}$ & $\begin{array}{l}\mathrm{cz}(198 \mathrm{bp} / 102 \mathrm{bp} / 96 \mathrm{bp} / 68 \\
\mathrm{bp} / 48 \mathrm{bp} / 20 \mathrm{bp} / 14 \mathrm{bp})\end{array}$ & $\begin{array}{l}\mathrm{dy}(280 \mathrm{bp} / 150 \mathrm{bp} / 96 \mathrm{bp} / 20 \\
\mathrm{bp} / 14 \mathrm{bp})\end{array}$ & $\begin{array}{l}\mathrm{dz}(280 \mathrm{bp} / 102 \mathrm{bp} / 96 \mathrm{bp} / 48 \\
\mathrm{bp} / 20 \mathrm{bp} / 14 \mathrm{bp})\end{array}$ \\
\hline
\end{tabular}


Table 3. Distribution of MHC-DQB1 genotypes in CE sheep and healthy controls

\begin{tabular}{|c|c|c|c|c|c|c|}
\hline $\begin{array}{c}\text { Genotype } \\
n=42\end{array}$ & $\begin{array}{c}\text { CE sheep } \\
\mathrm{n}=101\end{array}$ & $\begin{array}{c}\text { Healthy sheep } \\
n=103\end{array}$ & $\begin{array}{c}x^{2} \\
\text { with correction }\end{array}$ & $\mathrm{p}$ value & OR & $95 \% \mathrm{CI}$ \\
\hline \multicolumn{7}{|l|}{ MroxI-RFLP (3) } \\
\hline MroxI aa & $28(43.8 \%)$ & $31(44.9 \%)$ & 0 & $1, \mathrm{NS}$ & & \\
\hline MroxI ab & $25(39.1 \%)$ & $24(34.8 \%)$ & 0.11 & $0.74, \mathrm{NS}$ & & \\
\hline MroxI bb & $11(17.2 \%)$ & $14(20.3 \%)$ & 0.055 & $0.814, \mathrm{NS}$ & & \\
\hline \multicolumn{7}{|l|}{ ScaI-RFLP (3) } \\
\hline$S c a \mathrm{I}$ aa & $14(19.7 \%)$ & $10(11.8 \%)$ & 1.319 & $0.251, \mathrm{NS}$ & & \\
\hline ScaI ab & $57(80.3 \%)$ & $74(87.1 \%)$ & 0.865 & $0.352, \mathrm{NS}$ & & \\
\hline ScaI bb & $0(0 \%)$ & $1(1.2 \%)$ & 0 & $1, \mathrm{NS}$ & & \\
\hline \multicolumn{7}{|l|}{$N c i$ I-RFLP (3) } \\
\hline$N c i \mathrm{I} x \mathrm{x}$ & $66(70.2 \%)$ & $60(70.6 \%)$ & 0 & $1, \mathrm{NS}$ & & \\
\hline$N c i$ Igg & $20(21.3 \%)$ & $16(18.8 \%)$ & 0.049 & $0.824, \mathrm{NS}$ & & \\
\hline NciI xg & $8(8.5 \%)$ & $9(10.6 \%)$ & 0.07 & $0.792, \mathrm{NS}$ & & \\
\hline \multicolumn{7}{|l|}{ SacII-RFLP (7) } \\
\hline SacII aa & $37(59.7 \%)$ & $25(44.6 \%)$ & 2.098 & $0.147, \mathrm{NS}$ & & \\
\hline SacII bb & $0(0 \%)$ & $3(5.4 \%)$ & 1.589 & $0.207, \mathrm{NS}$ & & \\
\hline SacII cc & $7(11.3 \%)$ & $5(8.9 \%)$ & 0.014 & $0.905, \mathrm{NS}$ & & \\
\hline SacII ab & $4(6.5 \%)$ & $10(17.9 \%)$ & 2.651 & $0.103, \mathrm{NS}$ & & \\
\hline SacII ac & $8(12.9 \%)$ & $12(21.4 \%)$ & 0.974 & $0.324, \mathrm{NS}$ & & \\
\hline SacII ad & $5(8.1 \%)$ & $1(1.8 \%)$ & 1.279 & $0.258, \mathrm{NS}$ & & \\
\hline SacII bd & $1(1.6 \%)$ & $0(0 \%)$ & 0 & $1, \mathrm{NS}$ & & \\
\hline \multicolumn{7}{|l|}{ TaqI-RFLP (4) } \\
\hline TaqI aa* & $58(57.4 \%)$ & $85(82.5 \%)$ & 14.152 & $0, \mathrm{HS}$ & 0.286 & $0.150-0.544$ \\
\hline TaqI bb & $1(1 \%)$ & $1(1 \%)$ & 0 & $1, \mathrm{NS}$ & & \\
\hline $\operatorname{Taq} \mathrm{I} \mathrm{ab}^{* *}$ & $41(36.9 \%)$ & $17(16.5 \%)$ & 10.278 & 0.001,HS & 2.963 & $1.551-5.661$ \\
\hline TaqI ac & $1(1.6 \%)$ & $0(0 \%)$ & 0 & $0.992, \mathrm{NS}$ & & \\
\hline \multicolumn{7}{|l|}{ MvaI-RFLP (16) } \\
\hline$M v a \mathrm{I}$ aa & $3(3.6 \%)$ & $7(7.4 \%)$ & 0.576 & $0.448, \mathrm{NS}$ & & \\
\hline MvaI bb & $1(1.2 \%)$ & $0(0 \%)$ & 0.005 & $0.946, \mathrm{NS}$ & & \\
\hline$M v a \mathrm{I} \mathrm{cc}$ & $18(21.7 \%)$ & $13(13.7 \%)$ & 1.455 & $0.228, \mathrm{NS}$ & & \\
\hline$M v a I$ dd & $4(4.8 \%)$ & $12(12.6 \%)$ & 2.419 & $0.12, \mathrm{NS}$ & & \\
\hline$M v a \mathrm{I} \mathrm{zz}$ & $16(19.3 \%)$ & $22(23.2 \%)$ & 0.2 & $0.655, \mathrm{NS}$ & & \\
\hline MvaI yy & $14(16.9 \%)$ & $15(15.8 \%)$ & 0 & $1, \mathrm{NS}$ & & \\
\hline$M v a \mathrm{I}$ ad & $0(0 \%)$ & $1(1.1 \%)$ & 0 & $1, \mathrm{NS}$ & & \\
\hline$M v a \mathrm{I}$ az & $1(1.2 \%)$ & $3(3.2 \%)$ & 0.137 & $0.711, \mathrm{NS}$ & & \\
\hline$M v a \mathrm{I} b c$ & $1(1.2 \%)$ & $0(0 \%)$ & 0.005 & $0.946, \mathrm{NS}$ & & \\
\hline MvaI bd & $1(1.2 \%)$ & $0(0 \%)$ & 0.005 & $0.946, \mathrm{NS}$ & & \\
\hline$M v a \mathrm{I} \mathrm{bz}$ & $1(1.2 \%)$ & $0(0 \%)$ & 0.005 & $0.946, \mathrm{NS}$ & & \\
\hline MvaI by & $0(0 \%)$ & $2(2.1 \%)$ & 0.38 & $0.537, \mathrm{NS}$ & & \\
\hline MvaI cd & $6(7.2 \%)$ & $3(3.2 \%)$ & 0.799 & $0.371, \mathrm{NS}$ & & \\
\hline$M v a \mathrm{I} \mathrm{cz}$ & $14(16.9 \%)$ & $7(7.4 \%)$ & 2.983 & $0.084, \mathrm{NS}$ & & \\
\hline$M v a \mathrm{I} \mathrm{dz}$ & $2(2.4 \%)$ & $9(9.5 \%)$ & 2.692 & $0.101, \mathrm{NS}$ & & \\
\hline \multicolumn{7}{|l|}{ HaeIII-RFLP (6) } \\
\hline HaeIII aa & $0(0 \%)$ & $3(3.1 \%)$ & 1.376 & $0.241, \mathrm{NS}$ & & \\
\hline HaeIIImm & $32(33.0 \%)$ & $24(25.0 \%)$ & 1.133 & $0.287, \mathrm{NS}$ & & \\
\hline HaeIII nn* & $28(28.9 \%)$ & $55(57.3 \%)$ & 14.767 & $0, \mathrm{HS}$ & 0.303 & $0.167-0.550$ \\
\hline HaeIII am & $3(3.1 \%)$ & $1(1.0 \%)$ & 0.245 & $0.621, \mathrm{NS}$ & & \\
\hline HaeIII an & $3(3.1 \%)$ & $2(2.1 \%)$ & 0 & $1, \mathrm{NS}$ & & \\
\hline HaeIII mn** & $31(32 \%)$ & $11(11.5 \%)$ & 10.736 & $0.001, \mathrm{HS}$ & 3.629 & $1.699-7.755$ \\
\hline
\end{tabular}

$\mathrm{OR}=$ Odds ratio, $\mathrm{CI}=$ Confidence interval, $\mathrm{HS}=$ Highly significant, $\mathrm{S}=$ Significant, NS = Not significant.

“*” Means that these genotypes are associated with resistance to $\mathrm{CE}$, while “*** means that these genotypes are associated with susceptibility to $\mathrm{CE}$. 
Table 4. Frequencies of MHC-DQB1 alleles in CE sheep and healthy controls

\begin{tabular}{|c|c|c|c|c|}
\hline \multirow{2}{*}{$\begin{array}{l}\text { Alleles } \\
\mathrm{n}=22\end{array}$} & \multicolumn{2}{|c|}{ CE sheep } & \multicolumn{2}{|c|}{ Healthy sheep } \\
\hline & Number & Frequencies & Number & Frequencies \\
\hline \multicolumn{5}{|l|}{ MroxI- (2) } \\
\hline MroxI a & 81 & $63.28 \%$ & 86 & $62.32 \%$ \\
\hline MroxI b & 47 & $36.72 \%$ & 52 & $37.68 \%$ \\
\hline \multicolumn{5}{|l|}{ ScaI- (2) } \\
\hline ScaI a & 85 & $59.85 \%$ & 94 & $55.29 \%$ \\
\hline$S c a \mathrm{I}$ b & 57 & $40.15 \%$ & 76 & $44.71 \%$ \\
\hline \multicolumn{5}{|l|}{ NciI- (2) } \\
\hline$N c i \mathrm{I} x$ & 140 & $74.46 \%$ & 129 & $75.88 \%$ \\
\hline$N c i$ g & 48 & $25.54 \%$ & 41 & $24.12 \%$ \\
\hline \multicolumn{5}{|l|}{ SacII- (4) } \\
\hline SacII a & 91 & $73.39 \%$ & 73 & $65.18 \%$ \\
\hline SacII b & 5 & $4.03 \%$ & 16 & $14.29 \%$ \\
\hline SacII c & 22 & $17.74 \%$ & 22 & $19.64 \%$ \\
\hline SacII d & 6 & $4.84 \%$ & 1 & $0.86 \%$ \\
\hline \multicolumn{5}{|l|}{ TaqI- (3) } \\
\hline TaqI a & 187 & $90.78 \%$ & 158 & $78.22 \%$ \\
\hline $\operatorname{Taq} \mathrm{I} \mathrm{b}$ & 19 & $9.22 \%$ & 43 & $21.29 \%$ \\
\hline $\operatorname{Taq} \mathrm{I} \mathrm{c}$ & 0 & $0 \%$ & 1 & $0.51 \%$ \\
\hline \multicolumn{5}{|l|}{ MvaI- (6) } \\
\hline$M v a \mathrm{I}$ a & 7 & $4.22 \%$ & 18 & $9.47 \%$ \\
\hline$M v a \mathrm{I} b$ & 5 & $3.01 \%$ & 2 & $1.05 \%$ \\
\hline$M v a \mathrm{I} \mathrm{c}$ & 57 & $34.34 \%$ & 36 & $18.95 \%$ \\
\hline$M v a I \mathrm{~d}$ & 18 & $10.84 \%$ & 38 & $20 \%$ \\
\hline$M v a \mathrm{I}$ y & 29 & $17.47 \%$ & 33 & $17.34 \%$ \\
\hline$M v a \mathrm{I}$ z & 50 & $30.12 \%$ & 63 & $33.16 \%$ \\
\hline \multicolumn{5}{|l|}{ HaeIII- (3) } \\
\hline HaeIII a & 6 & $3.08 \%$ & 9 & $4.69 \%$ \\
\hline HaeIII m & 98 & $50.52 \%$ & 60 & $31.25 \%$ \\
\hline HaeIII n & 90 & $46.4 \%$ & 123 & $64.06 \%$ \\
\hline
\end{tabular}

CE group, which might be associated with resistance to $\mathrm{CE}$ (Table 3).

In contrast, we found that the frequencies of DQB1TaqIab and DQB1-HaeIIImn genotypes were significantly higher in the CE group (36.9\% and $32.0 \%$, respectively) than those in the healthy group $(16.5 \%$ and $11.15 \%$, respectively) $(\mathrm{p}=0.001,0.001$ and $\mathrm{OR}=2.963,3.629$, respectively), which might be associated with susceptibility to CE (Table 3).

Results of agarose gel electrophoresis for the two enzymes (TaqI and HaeIII), are illustrated in Figure 1 and 2.

\section{DISCUSSION}

It has been demonstrated that there are two main approaches, using polymorphisms, in the identification of genes involved in polygenic diseases. The first is examining inheritance patterns for genetic polymorphisms in family studies and the second is population case-control studies which compare genotype frequencies for candidate genes in individuals with the disease and healthy controls (Daly and Day, 2001). An MHC gene or region is considered to be associated with a particular disease if one or more alleles or genotypes are found to be more or less common in diseased individuals compared to control groups (Shiina et al., 2004). In this study, we investigated MHC-DQB1 loci and CE association in Chinese Merino sheep by comparing the frequency of genotypes in CE sheep and those in healthy individuals. This approach is feasible and has already been applied in MHC-DRB1 loci and CE association studies in Kazak sheep (Li et al., 2010), although the MHC loci detected is different.

Different methods have been employed for typing the MHC-DQB1 gene in various sheep breeds and have revealed extensive polymorphism at these loci. Feichtlbauer et al. (2000) used SSCP methods to detect MHC-DQB1 in Scottish Black-face sheep, who found 16 new alleles. In the present study, we applied the PCR-RFLP method to identify DQB 1 exon 2 polymorphisms in Chinese Merino sheep. A total of 22 alleles and 42 RFLP patterns were identified. The polymorphisms existed at the positions of the 226th, 246th, 231st, 217th, 213th, 198th, 192nd, 174th, 161st, 140th, 96th and 34th base pairs. The extensive diversity at many MHC loci provides a valuable source of genetic

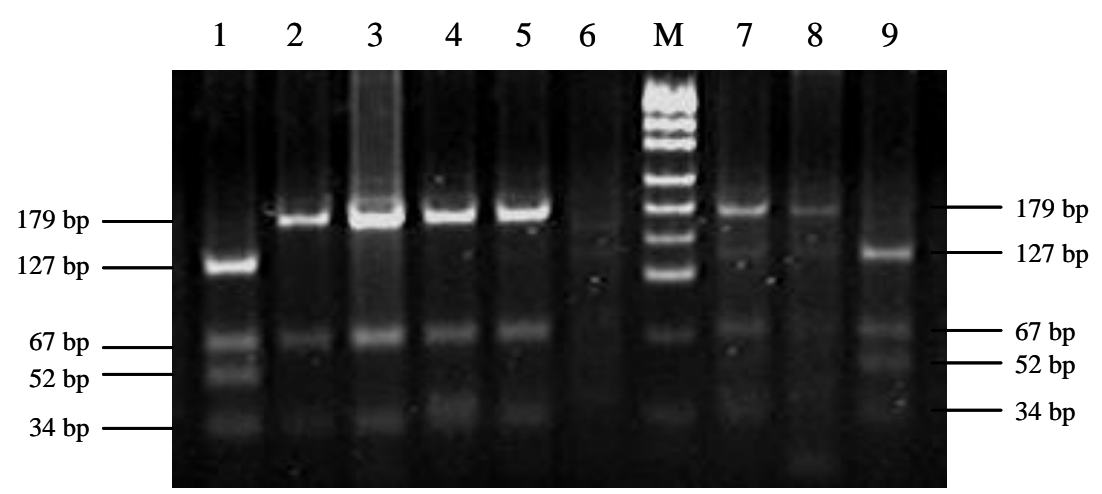

Figure 1. Electrophoretic patterns of the second exon of MHC-DQB1 digested with HaeIII in Chinese Merino sheep. lane1, 9: HaeIII mm; lane 2, 3, 4, 5: HaeIII nn; lane 7, 8: HaeIII mn; lane 6: free; M: puc19 DNA marker. 

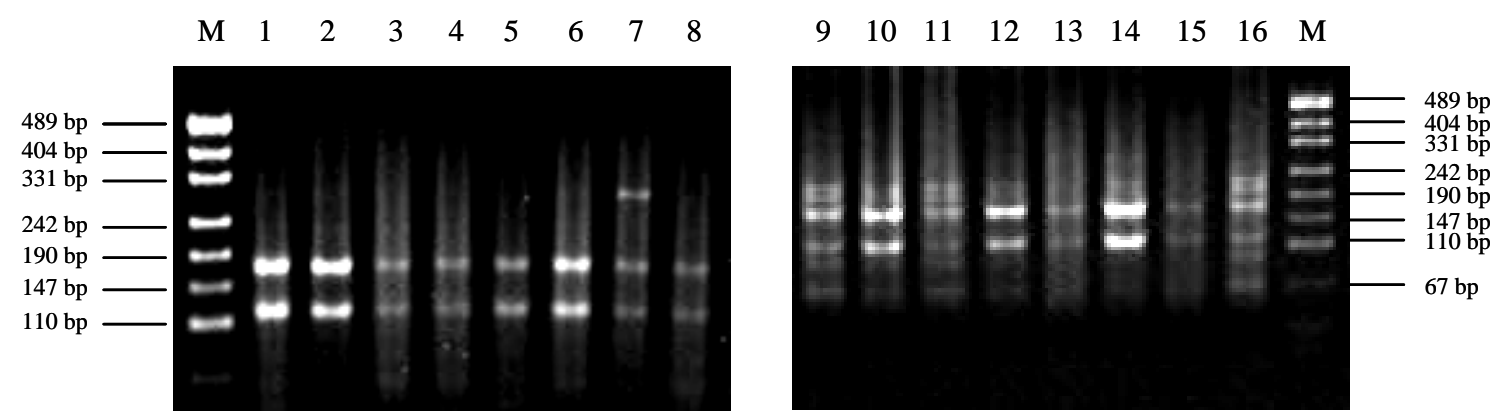

Figure 2. Electrophoretic patterns of the second exon of MHC-DQB 1digested with TaqI in Chinese Merino sheep. M: puc19 DNA marker; lane 1, 2, 3, 4, 5, 6, 8, 10, 12, 13, 14, 15: TaqI aa; lane 7: TaqI ac;lane 9, 11, 16: TaqI ab.

markers for examining the complex relationships between host genotype and disease resistance or susceptibility. For example, Sayers et al. (2005) suggested that the MHC gene plays an important role in the enhanced resistance of Suffolk sheep to nematode infection. In this study, the high polymorphism of MHC-DQB1 gene suggested that Chinese Merino sheep are excellent material for studying the relationship between $\mathrm{MHC}$ and disease resistance or susceptibility.

In the present study, we found that genotypes of DQB1TaqIaa and DQB1-HaeIIInn showed a negative statistically significant association with the occurrence of CE in Chinese Merino sheep, indicating that these genotypes might be suitable genetic resistant markers against CE. On the other hand, we also found that genotypes of DQB1-TaqIab and DQB1-HaeIIImn showed a positively significant association, indicating that they might be genetic markers of susceptibility to CE. Our previous study (Li et al., 2010) analyzed the relationship between MHC-DRB1 gene polymorphism and CE in Kazakh sheep by PCR-RFLP method, and found that the genotype of MvaIbc, Hin1Iab, HaeIIIdd, HaeIIIde, HaeIIIdf and SacIIab appeared to confer protection against $\mathrm{CE}$ in Kazakh sheep, while genotypes of MvaIbb, SacIIaa, Hin 1Ibb and HaeIIIef were found to confer susceptiblility to the disease. Comparing the present results with the above finding, however, there were also variation existing in the genotypes in terms of genetic markers, which may be related to the different loci of MHC genes, different sheep breed, or particularly due to genetic variation within the Echinococcus sp.

In conclusion, in the current circumstance there is a lack of information about the relationship between MHC and CE, this study reports within-breed genetic variation to parasite susceptibility/resistance to CE disease in Chinese Merino sheep, the results emphasized that MHC were significant factors for the development of $\mathrm{CE}$ or protection against $\mathrm{CE}$ in Chinese Merino sheep, which would pave the way for breeding disease resistance sheep in future. However, regarding that MHC-disease association is influenced by multiple factors, such as parasite disease biology, genetic background of animal, sample size and especially ovarMHC typing method, further work (e.g., sample amplification and experimental infection with $E$. granulosus) is required to carry out, which will provide more meaningful association.

\section{ACKNOWLEDGEMENTS}

We would like to thank the staff of the Veterinary Stations in the survey regions, who assisted in the collection of sheep blood samples.

\section{Financial support}

This research received the National Natural Science Foundation of China (Grant No. 31060297).

\section{REFERENCES}

Aida, Y. 2001. Influence of host genetic differences on leukemogenesis-induced bovine leukemia virus. AIDS Res. Hum. Retroviruses 17:5-31.

Amills, M., C. Sulasa, G. Bertonib, R. Zanonib and G. ObexerRuff. 2005. Nucleotide sequence and polymorphism of the caprine major histocompatibility complex class II DQA1 gene. Mol. Immunol. 42:375-379.

Charon, K. M., B. Moskwa, R. Rutkowski and J. Gruszczynska. 2002. Microsatellite polymorphism in DRB1 gene (MHC class II) and its relation to nematode faecal egg count in Polish Heath sheep. J. Anim. Feed Sci. 11:47-58.

Conchedda, M., F. Gabriele and G. Bortoletti. 2008. Morphological study of anomalous "laminated" brood capsules in cystic echinococcosis in humans and sheep. Acta Trop. 105: 215-221.

Daly, A. K. and C. P. Day. 2001. Candidate gene case-control association studies: advantages and potential pitfalls. Br. J. Clin. Pharmacol. 52:489-499.

Dorak, M. T. 2006. Statistical analysis in HLA and disease association studies, Workshop at BSHI 2002 meeting, Scotland (accessed: http://www.dorak. info/hla/stat.html at 25/2/2007).

Escayg, A. P., J. G. H. Hickford and D. W. Bullock. 1997. Association between alleles of the ovine major histocompatibility complex and resistance to footrot. Res. Vet. Sci. 63:283-287. 
Feichtlbauer-Huber, P., M. J. Stear, R. Fries and J. Buitcamp. 2000. Reference-strand-mediated conformation analysis of MHC alleles: a new method for high-resolution typing of the ovarDQB genes. Immunogenetics 51:65-68.

Hui, W. Q., B. Jia, Z. S. Zhao, Y. C. Du and H. Shen. 2012. Differential expression of MHC-DQB1 mRNA in Chinese Merino sheep infected with Echinococcusus granulosus. Parasitol. Res. 110:2075-2079.

Hui, W., X. Du, B. Jia, X. Liu, Muyesaer, J. Ma and S. Ma. 2012. Seroprevalence of cystic echinococcosis in Chinese Merino and duolang sheep in Xinjiang, China. Pak. Vet. J. 32:459-461.

Klein, J. 1986. The natural history of the major histocompatibility complex. Wiley, New York, USA, pp. 56-79.

Konnai, S., Y. Nagaoka, S. Takesima, M. Onuma and Y. Aida. 2003a. DNA typing for ovine MHC-DRB1 using polymerase chain reaction restriction fragment length polymorphism (PCR-RFLP). J. Dairy Sci. 86:3362-3365.

Konnai, S., S. Takesima, S. Tajima, S. A. Yin, K. Okada, M. Onuma and Y. Aida. 2003b. The influence of ovine MHC class II DRB1 alleles on immune response in bovine leukemia virus infection. Microbiol. Immunol. 47:223-232.

Larruskain, A., E. Minguijón, K. García-Etxebarria, B. Moreno, I. Arostegui, R. A. Juste and B. M. Jugo. 2010. MHC class II DRB1 gene polymorphism in the pathogenesis of Maedi-Visna and pulmonary adenocarcinoma viral diseases in sheep. Immunogenetics 62:75-83.

Li, R. Y., B. Jia, W. J. Zhang, Z. S. Zhao, G. Q. Shi, H. Shen, Q. Peng, L. M. Lv, Q. W. Zhou and Y. C. Du. 2010. Analysis of the relationship between MHC-DRB1 gene polymorphism and hydatidosis in Kzazkh sheep. Asian-Aust. J. Anim. Sci. 23: 1145-1151.

Lightowlers, M. W., O. Jensen, E. Fernandez, J. A. Iriarte, D. J. Woollard, C. G. Gauci, D. J. Jenkins and D. D. Heath. 1999. Vaccination trials in Australia and Argentina confirm the effectiveness of the EG95 hydatid vaccine in sheep. Int. J. Parasitol. 29:531-534.
Millot, P. 1978. The major histocompatibility complex of sheep (OLA) and two minor loci. Anim. Blood Groups Biochem. Genet. 9:115-121.

Outteridge, P. M., L. Andersson, P. G. Douch, R. S. Green, P. S. Gwakisa, M. A. Hohenhaus and S. Mikko. 1996. The PCR typing of MHC-DRB genes in the sheep using primers for an intronic microsatellite: application to nematode parasite resistance. Immunol. Cell Biol. 74:330-336.

Sangster, N. C. 1999. Anthelmintic resistance: past, present, and future. Int. J. Parasitol. 29:115-124.

Sayers, G., B. Good, J. P. Hanrahan, M. Ryan, J. M. Angles and T. Sweeney. 2005. Major histocompatibility complex DRB1 gene: its role in nematode resistance in Suffolk and Texel sheep breeds. Parasitology 131:403-409.

Shiina, T., H. Inoko and J. K. Kulski. 2004. An update of the HLA genomic region, locus information and disease associations. Tissue Antigens 64:631-649.

Stear, M. J., G. T. Innocent and J. Buitkamp. 2005. The evolution and maintenance of polymorphism in the major histocompatibility complex. Vet. Immunol. Immunopathol. 108:53-57.

Sun, D. X. and Y. Zhang. 2004. Polymorphism of the second exon of MHC-DRB gene in Chinese local sheep and goat. Biochem. Genet. 42:385-390.

Torgerson, P. R. 2003. Economic effect of echinococcosis. Acta Trop. 85:113-118.

Woodal, C. J., L. J. Maclaren and N. J. Watt. 1997. Differential levels of mRNAs for cytokines, the interleukin-2 receptor and class II DR/DQ genes in ovine interstitial pneumonia induced by maedi visna virus infection. Vet. Pathol. 34:204-211.

Zhang, W. B., J. Li and D. P. McManus. 2003. Concepts in immunology and diagnosis of hydatid disease. Clin. Microbiol. Rev. 16:18-36. 